Wieś i Rolnictwo 4 (189)/2020

ISSN 0137-1673

E-ISSN 2657-5213

doi: 10.7366/wir042020/01

\title{
David Freshwater
}

\section{Major Forces Affecting Rural Regions in 2020}

\begin{abstract}
Rural regions in OECD countries have always faced development challenges, resulting from their: reliance on natural resources, small labour forces, and long distances from markets, as well as the effects of globalization. Now, in addition, their development opportunities are further constrained by: climate change requirements, increased economic fragility resulting from COVID and the lingering effects of the 2008 recession, and the uneven impacts of the Internet economy. But, from a rural development policy perspective, perhaps the most important new challenge is the rise of rural populism. While rural areas and people have long been seen as distinct from their urban counterparts, in the last two decades these gaps have grown. Importantly, while the internet and information and communications technology (ICT) were initially seen as providing opportunities to improve social cohesion and link rural and urban people and places, instead they seem to have increased tensions. Because the core values of urban and rural people have grown so far apart, it is more difficult to establish the political compromises that are required to form effective policy. Absent some reconciliation of these social and political differences, it is difficult to see how national government policy can evolve to meet new challenges. Consequently, the likelihood of national governments being able to identify and implement coherent rural development policies is reduced.
\end{abstract}

Keywords: rural development, rural/urban divide, social conflict, rural policy, populism.

\section{Introduction}

The paper examines major forces that are likely to shape rural areas in OECD countries in current years. It builds upon a short paper on the future of rural America at the turn of the century that I was asked to write in 2000 (Freshwater 2000). In it I identified eight challenges that I believed would condition future

David Freshwater, PhD, Professor, Department of Agricultural Economics, University of Kentucky, 400 Charles E. Barnhart Building, Lexington, KY 40546-0276, United States of America, e-mail: dfresh@ uky.edu, ORCID: 0000-0002-7668-0861. 
rural prosperity. They were all commonly accepted macro forces that had already shaped rural economics in the United States, as well as in other OECD countries, and were expected to continue to remain important. Now, in 2020, although these eight challenges remain, there are new factors that I failed to anticipate. These are in many ways both more powerful and less subject to influence by conventional rural policy. This requires that they be shaped by a much broader set of national policies and social changes that will be more difficult for countries to implement, but are vital for the well-being both of urban and rural people. This has important implications for rural policy. While it is possible to identify rural specific policies that can address the forces identified in 2000 , the new forces require comprehensive national, or multi-national responses, but ones that are sensitive to urban and rural differences.

\section{New Forces for Rural Change}

In 2020 we must now think about at least an additional four additional forces. First, we are now fully aware that climate change is having a major impact on the entire world, including rural areas. Second, the Great Recession of 20082009 had an important and continuing impact on global finance, and its long-term effects remind us that national economies remain susceptible to large-scale financial shocks despite the sophistication of banks and monetary authorities. Most recently, the COVID-19 pandemic has led to another global recession, albeit one that was induced by national governments as a response to the rapid spread of the virus, again demonstrating the power of major shocks. As a result, we must accept that large unforeseen shocks can radically reshape how our economies function, leading to a significant increase in economic fragility.

Third, as early as 1991, the impact of the internet on rural areas was evident (OTA 1991), and by 2000 the rural gaps in access to basic computer connectivity were apparent (Parker 2000). However, in 2020 the role of all forms of internet and wireless connectivity in our economy and society is astounding. And, while most rural areas have access to most electronically enabled services such as cell-phones, social media and e-commerce, this access remains slower, more expensive, less reliable and less useful in rural than in urban areas. Beliefs that the internet would result in the death of distance have largely been refuted (Weber and Freshwater 2016). Instead, the internet has enabled early adopters, typically located in large metropolitan regions, to dominate major new services, for example, social media, e-commerce, cloud computing, e-learning and tele-medicine. In particular, continuous rapid innovation in mobile phone technologies, both hardware and applications, are first introduced in urban areas and then slowly diffuse. While rural 
people clearly benefit from these services, and may actually benefit more than urban residents do, the advances are largely conceived of, designed and implemented to serve urban customers.

But perhaps the most unexpected force has been a growing social divide between urban and rural societies in many OECD countries. Instead of increased economic integration and the widespread use of social media leading to societies that are more harmonised, it seems that these forces have contributed to increased economic inequality and social polarisation. One dimension of this is a growing tension between urban and rural people. Finally, globalisation, while not a new factor, continues to remain as important as it was in 2000, but in a very different way. In 2000 our expectations were that global integration would continue and that increasing trade flows would lead to a steady process of market liberalisation that would benefit all countries. In the last four years this view has been challenged by major disruptions to global trade in the form of tariff wars, increasing use of nontariff barriers to protect domestic firms, and most recently a growing desire to increase the self-supply of food and essential medical supplies as a reaction to the pandemic.

\subsection{Climate Change}

Climate change is now largely accepted by most people. Rural areas experience the effects of climate change more directly because people remain more directly exposed to all forms of nature than is the case for urban populations. Agriculture is perhaps the clearest example of climate effects, including changes in precipitation patterns, shifts in seasonal temperatures and resulting changes in the spatial pattern of crop cultivation. But other rural activities are also affected, including forestry and tourism. In addition, rural areas are more highly exposed to efforts to mitigate climate effects. In particular, taxes on fossil fuels will have a disproportionality larger effect in rural regions because much of what they buy and sell involves long transport distances.

\subsection{Economic Fragility}

At the turn of the century there was a general consensus that while business cycles continued to exist, the chances of a major economic decline were small. But in 2000 the dot.com bubble burst, causing a sharp recession that wiped out many of the first wave of internet stocks. While this recession had limited impact on rural areas, in hindsight it was the first warning of a new economic fragility. The 20082009 recession had significant effects on rural areas because it was a financial crisis 
that affected virtually all lenders. As a result, firms lost access to credit lines and loans became more difficult to obtain. For small firms, which make up the majority of businesses in rural regions, the consequences were especially severe. Such firms rely more on debt finance and have limited cash reserves relative to larger publicly traded corporations. A third major economic shock in 2020 triggered by the COVID pandemic makes it clear that, despite the efforts of central banks, economic stability can no longer be counted on.

For households, firms and governments in rural areas the consequences of higher levels of economic fragility are significant. Although interest rates may remain low for some time, lenders are more cautious about extending credit and many borrowers are reluctant to borrow because they fear another economic downturn. This should lead to lower rates of economic growth and fewer investments that can increase worker productivity. Because rural areas rely more on tradables then urban regions do, they are especially exposed to slower rates of growth and weaker investment (OECD 2016).

In 2020, while the initial impacts of the COVID pandemic were first felt in urban areas, they have now spread to rural areas, where they can be particularly onerous (OECD 2020). COVID disproportionately affects the elderly, those with pre-existing health conditions, and those with more limited access to healthcare facilities, and rural areas also have a higher percentage of individuals in these circumstances. Moreover, fewer rural workers are able to work remotely and a large share are employed in the tourism and hospitality sectors, which have been greatly impacted by shut-downs and falling demand.

\subsection{The Internet Economy}

In the last two decades the role of internet-based telecommunications has radically changed the global economy and our societies. In particular smartphones have displaced personal computers as the main means by which people access the internet. Mobile internet access allows people to be connected in multiple ways at any point in time. In most rural areas many of the main benefits of this connectivity are available, including weather information, commodity prices, news, social media feeds, etc. Internet shopping is at least as prevalent in rural areas as in urban areas, although the delivery process is significantly slower.

People and firms in rural regions now have more access to goods and services than ever before, because they are no longer restricted to what is locally available. Rural businesses with an internet presence now have the same opportunity as large urban firms to be visible to potential customers across an entire nation or multiple nations. For rural firms that serve spatially dispersed niche markets the benefits are 
huge. But rural businesses now face significant external competition for customers. They are no longer protected by the barrier of distance (Weber and Freshwater 2016). An important social consequence of this broadened connectivity has been a weakening of ties within rural communities. While cities became the home of a wide variety of communities of interest a long time ago, people in rural towns and villages were largely bound together in a shared community of place, because they had limited access to the wider society. Social media now provides a way for people in even the smallest village to find and connect with people around the nation who have similar values, concerns and attitudes. And with social media it is easy for rural people to develop different ways of thinking than their proximate neighbours, and this can fragment communities.

Emerging technologies in distance learning, tele-medicine and internet-based government service delivery offer potentially large benefits for rural places, because they all address the challenges of long distance, low density and lack of scale that characterise rural regions. In most OECD countries nascent efforts to develop and implement these technologies in rural regions have recently been accelerated in response to the COVID pandemic. Because of the pandemic schools, medical care providers and local governments in urban areas are racing to find ways to deliver services to people remotely, even though they are located nearby (OECD 2020). This new urban demand for e-services may shrink as the pandemic effects weaken, but the new capabilities that are being created will continue to have major benefits in rural regions where they provide access that was unavailable through traditional delivery methods.

\subsection{The Rural/Urban Divide}

While we have always accepted that there are differences between urban and rural places, now there is a growing sense that these differences have increased to the point that they influence national politics. Historically, most countries recognised that rural places have a different economic function than urban ones and that place-based policies to mitigate differences in economic outcomes were appropriate. Even so, despite economic differences, there was a sense that rural and urban people shared a common society. As long as this was true it was possible to develop mechanisms to mitigate economic inequality.

Over time, economic differences seem to have been transformed into geographic differences, and from there into social differences. For example, in the United States the Joint Economic Committee of Congress released a report in 1986 on the BiCoastal Economy, which examined patterns of regional economic growth and concluded that growth was concentrated in a small number of states located on 
either the Atlantic or Pacific coasts, and that most interior states had performed poorly (JEC 1986). In 2004 Thomas Frank examined why many people in Kansas, a largely rural state, had come to identify with the Republican party, whose core economic policies were clearly detrimental to their economic interests (Frank 2004). He concluded that, for these individuals, conservative social values were more important in making political choices than their economic interests were.

Initial analysis of the 2020 US election shows a strengthening of the divide since 2016 (Zitner and Chinni 2020). This year Biden won the largest 25 counties and 91 of the largest 100 counties in the US. This, however, was only $17 \%$ of all counties, although these counties accounted for $71 \%$ of US GDP. Conversely, Trump won $83 \%$ of all counties, accounting for $29 \%$ of GDP. According to the authors, these results mark a continuation of trends going back to the 1980s. Counties voting for Biden tended to have a higher share of college-educated workers, higher average incomes, faster employment and population growth, and a greater share of whitecollar workers. Consistent with Frank's assessment of Kansas voters, support for Trump was strongest among those counties that benefited the least from his economic policies, but arguably, were most in favour of his social policies.

\subsection{Rise of Region-Specific Social Conflict}

What was controversial in 1986 has now become common, with interior US states regularly referred to as "flyover country" or disparaged as being economically and socially backward. What is different in 2020 is that the divergence is more often framed as being between highly skilled, progressive, globalist urbanites who live in large prosperous cities, and conservative, low-skill, nativist rural people who live in declining small towns and who depend on government transfers. In the United States this gap is now often framed as a red-state vs. blue-state divide, with one political party being dominant in each case. Somehow what was initially described in terms of differences in regional economic performance has been transformed into a broad and corrosive fight between urban and rural people.

Other countries have experienced their own versions of regional differences being transformed into social differences based largely on a rural-urban dichotomy. In Canada tensions over petroleum development pit resource-dependent western provinces against an urban population in large cities in Ontario and Quebec who have little economic interest in supporting resource extraction. Brexit appears to have been driven by a rejection of the EU by people in the more rural and lesseconomically prosperous north and midland regions, while people in the more prosperous and highly urbanised south-east were mainly "remain voters". Poland is experiencing significant tensions between a more religious and conservative 
rural populace and more progressive urban society in the large cities. In France the gilets-jaune demonstrations in 2018 were led mainly by people from more rural areas in response to proposed increases in gasoline taxes, which were mainly designed to reduce automobile use in large cities where mass transit is a viable travel choice (Zerofsky 2018). More generally, Euroscepticism is strongly associated with a non-metropolitan location (Schoene 2019).

\subsection{Rural Populism in the Past}

In all these cases some specific regional differences, typically of an economic nature, became transformed into a highly polarised fight between an "oppressed rural population" and a dominant "urban elite". It is this re-emergence of populism, which was thought to be a long dormant ideology, that is perhaps the most crucial challenge for rural development in the next decades. The classic populist model consists of two groups and a dynamic (Holmes 1990; Mudde and Kaltwasser 2017). The first group consists of people who believe they are the true base of society and embody its core values. The second group are an elite that controls the political process, but that has lost touch with the people and only acts in its narrow selfinterest. The dynamic involves political organisation by "the people" to take back control of the government as a necessary first step to remove the power of the élites.

Populism as a political concept had its origins as a rural urban conflict in late 18th-century America, when farmers in the middle of the country believed they were being harmed by bankers, processors and railroads who made excessive monopoly profits. Moreover, they saw the national government as a tool of these urban elites. Only by seizing control of the government could they expect to break the monopolists' power. To do this required the construction of a new political force that could break the power of existing parties. But while farmers believed they reflected the core values of society they failed to persuade others to support their cause. Ultimately, while the populist farm movement made some progress in economic reform it failed to gain enough support to have much electoral success (Mayhew 1972). Notably, this was at a time when farmers were by far the majority of the rural population, and the rural population was still just under half the population of the United States. In reality farmers gained more in the early 1900s from the efforts of the subsequent progressive movement - a mainly urban coalition of people who wanted to overthrow corruption, reduce the influence of business on government and use government to improve social well-being (Filene 1970; Nugent 2009). Unlike the populists, who had a narrow political base and lacked financial resources and actual political experience, the progressives started by gaining control of local governments and delivering well-received results 
enabling them to gain credibility and financial backing that in turn led to national electoral success.

\subsection{The New Rural Populism}

What might this history lesson suggest for rural people today? While the agrarian populists had legitimate complaints about the abuse of economic power by banks, processors and railroads, the full picture was more complicated and the low prices and high freight rates farmers experienced were often the result of actual market forces and not monopoly power (North 1966). More importantly, while America had been largely an agrarian nation, by the 1880 s it was rapidly industrialising and the values of farmers were no longer the values of the majority of the American public. Although farmers believed they spoke for all the people, in reality they were only a particular interest group, albeit an important one. Crucially, farmers were a protest movement and lacked both a coherent reform strategy and the credibility and organisational capacity to support their agenda.

In OECD countries the rural population is now a minority. While it remains the custodian of most nations' cultural history, it no longer reflects the current values of the majority of the people. Because rural people live in relative isolation and have diverse socio-economic circumstances it is difficult for them to organise. And while social media have made it easier for all interest groups to connect with likeminded people, there is still a major challenge of bringing the people and sufficient resources into an effective organisation. Almost by nature, populists are defined by what they oppose, and lack a common sense of what they are for, especially when the movement is made up of many interests. Large populist movements today, for example the Five- Star party in Italy, bring people with diverse interests together and while this diversity provides a larger political base it greatly complicates the ability to govern if they achieve power. Similarly, the Tea Party movement in the US united around opposition to taxes, but members split on which government programmes should be cut as consequence of reduced revenue.

\section{Reprise of the Eight Forces from 2000}

This section summarises the argument of my 2000 paper, mainly to provide a context for the new forces. Rural areas continue to remain more dependent on the primary sectors - agriculture, fishing forestry, mining and energy - than do metropolitan regions. These tradables provide an important source of revenue but a shrinking share of employment and are subject to considerable price swings, which lead to booms and busts. In the last decade, price volatility has occurred for 
both agriculture and energy when production exceeded demand. Ongoing market shifts and technological change can further exacerbate rapid shifts in revenue and employment, which make rural places more fragile. In addition, rural places have become more economically coupled to urban centres over time as transport costs continue to fall and globalisation has allowed a few manufacturing plants, often in China, to dominate the production of a wide range of goods. More recently, globalisation and enhanced electronic communication has extended the scope for off-shoring of services that in earlier times might have located in rural areas, for example call centres and back-office support centres.

Services now play a larger role in rural economies, but rural service delivery is challenged by high costs due to distance, low density and lack of scale (OECD 2010). In addition, rural services tend to be more limited in scope, with an absence of more specialised services and only one or two service providers being available, which limits competition and increases pricing power. While rural areas may have similar shares of workers in education or finance as urban regions, the rural workers in schools are unlikely to be in post-secondary education and in banking are unlikely to be in commercial lending or advanced financial services. As rural communities lose population while metropolitan regions grow, these gaps in the variety and range of services become larger.

Of the eight forces, globalisation has changed the most since 2020. In the last decade a steady shift to more open economies has slowed and may reverse. Shortages of medical equipment associated with the COVID pandemic have only increased questions about the cost of outsourcing key goods and services, especially when one country has become the primary, if not sole, supplier. Trade tensions have become common in the last few years, even among countries that share common values, and it is unlikely that they will disappear. What this means for rural regions in the OECD countries is uncertain. Those manufacturing jobs that left rural areas in the last part of the 20th century did so because China offered three key advantages - low-cost labour, a large home market and the ability to host very large facilities that could exploit economies of scale. While the risks associated with long supply chains and single suppliers are now more fully recognised, there will be limits on how much manufacturing will return to the OECD members, since China remains a formidable competitor and other developing counties offer significant locational advantages. Nevertheless, it may be possible to use a combination of new technologies and skilled labour to make smaller plants more productive, and this combined with a desire for self-supply or even multiple domestic suppliers for risk mitigation reasons could result in new rural manufacturing opportunities. 


\section{The Potential for a New Rural Policy}

Most OECD countries continue to recognise the need for a rural policy, even as they struggle to identify effective ones (Freshwater and Trapasso 2014). While rural policy is widely recognised as being more than agricultural policy there is no consensus on the specifics. This lack of specificity can be explained by the diversity of the rural situation, with rural communities in the same country or region having very different circumstances and opportunities. Some of this diversity is captured by rural typologies that focus on distance from a metropolitan region as a way to understand rural differences (OECD 2016). But rural communities the same distance from the same metropolitan region can experience sufficiently different situations to make their opportunities dissimilar. Further, few national governments make even minimal efforts to develop policies that explicitly consider rural and urban differences. Examples are numerous. Countries impose gasoline taxes to encourage people to use public transit, but public transit is only available in urban areas. Countries allow school choice as a way to incentivise better school management, but in rural areas there is only one school available. Governments establish waste-water treatment policies that specify particular technologies that work well in an urban area, but are not practical in rural areas. National governments provide funding to local governments through a competitive grant process, but small communities cannot afford to hire a grant writer, cannot meet eligibility criteria, or do not meet the minimum funding criteria.

The idea of "narrow" and "broad" rural policy can be used to frame a way to think about rural policy. Narrow rural policies are targeted only at rural areas and are inherently place specific, for example farm support. Broad policies apply nationally and have no explicit place focus, for example judicial codes. Countries have largely relied on narrow policies, in sector-specific or place-specific forms, to address rural needs. But many broad policies, including healthcare, environmental standards and education, are applied uniformly in all places, even though they have different impacts for rural and urban areas. Recently, the idea of "mainstreaming" has been employed by some counties in the belief that rural and urban areas are no longer different enough to warrant a distinct rural policy (Hodge 2003; Overman and Gibbons 2011). Yet conditions today suggest that perceived differences are increasing.

What form does rural policy take in this world of a growing rural-urban divide? Clearly it has to be different from what we do now. A simple first step is to recognise that broad policies offering exactly the same programmes in rural and urban areas often lead to very different outcomes, in part because conditions are different but also because the expectations of people differ. Equal treatment may not be equitable 
treatment if it systematically produces different outcomes, or produces a single outcome that is not wanted in some parts of a country. While narrow policies were reasonably effective when problems were largely economic, it is difficult to address social differences within a country by adopting place-specific policies. If populism is understood as a symptom of a significant part of society feeling that it is being treated unfairly by the economic or political structure, it is unlikely it will be appeased by minor improvements in standards of living.

More effective policy for rural areas is going to have to be "broadly" conceived, in that it will be conceptually "broad" in coverage, but allow some flexibility in how it is implemented in different places. Much of this policy will have to be social, rather than economic, because the divide is now as much driven by differences in social values as economic conditions. This is a far more complex challenge than integrating markets, but without efforts to rebuild a common set of values within a country the prospects for reductions in political tension are not good. And without political cohesion the prospects for economic development are also poor.

\section{Conclusion}

In 2000 I argued that rural development required ongoing investments in people, companies and infrastructure to overcome the eight challenges (Freshwater 2000, p.6). Twenty years later the situation still exists, and may be more crucial. Currently, interest rates are so incredibly low that such investments have low costs. Moreover, other reasons for making them are more important than a decade ago. These include the increased desire to reduce the risks of long supply chains, concerns that China is not interested in adopting the core values of OECD countries - a democratic government and a market economy, the need to replace an ageing workforce with a smaller number of better skilled and more productive workers, reflecting shrinking populations, and a sense that one form of the economic inequality that plagues our societies is lower opportunity and worse outcomes in rural regions.

Importantly, in 2000 there was a sense that, while urban and rural had differences, there was a strong and growing integration based on comparative advantage and increased social interaction (Champion 2007; Isserman 2001; OECD 2006; Schaeffer, Loveridge and Weiler 2014; Ward and Brown 2006). The main challenge for rural development was to find appropriate policy mechanisms that could better link rural and urban economies and improve the joint well-being of all citizens. The problems were largely seen as economic and could be addressed by improvements in markets and a modest income redistribution. Implicit in this was the belief that social and cultural differences within a country did not have 
a strong rural and urban dimension, so it was possible to assume that rural and urban people wanted the same things.

Now it seems this is not so clear. To the extent that rural and urban people want a fundamentally different society, there are few options for government policies to mutually satisfy these different values. It is difficult for national governments to have different social policies in different parts of a country. These differences are increasingly exacerbated by social media, because it provides individuals with news and opinions that are constantly adjusted to reinforce personal preferences. Attitudes regarding the danger of COVID are part of the social divergence, as fewer rural residents believe stringent restrictions on personal behaviour are justified than is the case for urban areas. Similarly, addressing climate change will require adjustments in economic policies, but before these can be introduced there has to be a more complete acceptance of the need to make major adjustments.

\section{References}

Champion T. (2007). Defining "urban": The disappearing urban-rural divide. In: Geyer H.S. (ed.), International Handbook of Urban Policy, vol. 1 (pp. 22-37). Cheltenham: Edward Elgar.

Filene P. (1970). An obituary for the "Progressive Movement”. American Quarterly, 22 (1), $20-34$.

Frank Th. (2004). What's the Matter with Kansas? New York: Henry Holt and Company.

Freshwater D. (2000). Rural America at the turn of the century: One analyst's perspective. Rural America, 15 (3), 2-7.

Freshwater D., Trapasso R. (2014). The Disconnect between Principles and Practice: Rural Policy Reviews of OECD Countries. Paris: OECD Publishing.

Hodge I. (2003). Mainstreaming rural development policy under the CAP. Journal of Environmental Policy and Planning, 5 (3), 361-378.

Holmes W. (1990). Populism: In search of context. Agricultural History, 64 (4), 26-58.

Isserman A. (2001). Competitive advantages of rural America in the next century. International Regional Science Review, 21 (1), 38-58.

JEC (Joint Economic Committee of Congress) (1986). The Bicoastal Economy: Regional Patterns of Economic Growth during the Reagan Administration. Washington, D.C.: Government Printing Office.

Mayhew A. (1972). A reappraisal of the causes of farm protest in the United States, 18701905. The Journal of Economic History, 32 (2), 464-475.

Mudde C., Kaltwasser C. (2017). Populism: A Very Short Introduction. Oxford: Oxford University Press.

North D. (1966). Growth and Welfare in the American Past. Englewood Cliffs, NJ: PrenticeHall.

Nugent W. (2009). Progressivism: A Very Short Introduction. Oxford: Oxford University Press. 
OECD (Organisation for Economic Cooperation and Development) (2006). The New Rural Paradigm. Paris: OECD Publishing.

OECD (Organisation for Economic Cooperation and Development) (2010). Strategies to Improve Rural Service Delivery. Paris: OECD Publishing.

OECD (Organisation for Economic Cooperation and Development) (2016). OECD Regional Outlook: 2016. Paris: OECD Publishing.

OECD (Organisation for Economic Cooperation and Development) (2020). Policy Implications of Coronavirus Crisis for Rural Development. Paris: OECD Publishing. Available: http://www.oecd.org/coronavirus/policy-responses/policy-implications-of-coronavirus-crisis-for-rural-development-6b9d189a/

OTA (Office of Technology Assessment) (1991). Rural America at the Crossroads. Office of Technology Assessment. Washington, D.C.: US Government Printing Office.

Overman H., Gibbons S. (2011). The Future of Rural Policy: Lessons from Spatial Economics. SERC Policy paper 8. London: London School of Economics. Available: http://eprints. lse.ac.uk/59234/1/_lse.ac.uk_storage_LIBRARY_Secondary_libfile_shared_repository_Content_LSE\%20Spatial\%20Economic\%20Research\%20Centre_SUNAINA\%20 SERC_sercpp008.pdf

Parker E. (2000). Closing the digital divide in rural America. Telecommunications Policy, 24 (2), 281-290.

Schaeffer P., Loveridge S., Weiler S. (2014). Urban and rural: Opposites no more! Economic Development Quarterly, 28 (1), 3-4.

Schoene M. (2019). European disintegration? Euroscepticism and Europe's rural/urban divide. European Politics and Society, 20 (3), 348-368.

Ward N., Brown D. (2009). Placing the rural in regional development. Regional Studies, 43 (10), 1237-1244.

Weber B., Freshwater D. (2016). The death of distance? Networks, the costs of distance and urban-rural interdependence. In: Shucksmith M., Brown D. (eds.), Routledge International Handbook of Rural Studies (pp. 154-164). Routledge: New York.

Zerofsky El. (2018). The Gilets Jaunes movement. The New Yorker, December 13, 2018. Accessed June 26, 2020 at https://www.newyorker.com/news/news-desk/the-complicated-politics-of-the-gilets-jaunes-movement

Zitner A., Chinni D. (2020). How the 2020 election deepened America's white-collar/ blue-collar split. Wall Street Journal, November 24, 2020. Available: https://www.wsj. com/articles/how-the-2020-election-deepened-americas-white-collar-blue-collar-split-11606219208?mod=politics_lead_pos3 


\section{Główne siły oddziałujące na regiony wiejskie w 2020 r.}

Streszczenie: Regiony wiejskie w krajach OECD zawsze borykały się z wyzwaniami rozwojowymi wynikającymi z: zależności od zasobów naturalnych, niewielkich zasobów pracy, dużych odległości od rynków, a także skutków globalizacji. Obecnie ich możliwości rozwojowe są dodatkowo ograniczone przez: wymagania wynikające ze zmian klimatycznych, zwiększoną niestabilność i „wrażliwość” gospodarczą - wynikającą z pandemii COVID-19, utrzymujące się skutki recesji z 2008 r. oraz nierównomierny wpływ gospodarki internetowej. Jednak z perspektywy polityki rozwoju obszarów wiejskich być może najważniejszym nowym wyzwaniem może okazać się wzrost populizmu na wsi. Mieszkańcy obszarów wiejskich od dawna są odmiennie postrzegani niż mieszkańcy miast, w ciągu ostatnich dwóch dekad różnice między tymi grupami wzrosły. Co ważne, chociaż początkowo postrzegano internet oraz technologie informacyjno-komunikacyjne (ICT) jako narzędzia, które mogą poprawić spójność społeczną oraz integrować różne obszary oraz ludność miejską i wiejską, to obecnie wydaje się, że zamiast tego spowodowały zwiększenie napięć między nimi. Ponieważ podstawowe wartości mieszkańców miast i wsi kształtowały się odrębnie, dlatego bardzo się różnią i trudno jest osiągnąć polityczny kompromis wymagany do stworzenia skutecznej polityki rządów krajowych. W konsekwencji zmniejszają się szanse na to, że rządy krajowe będą w stanie stworzyć i wdrożyć spójną politykę rozwoju obszarów wiejskich.

Słowa kluczowe: rozwój wsi, podział miasto - wieś, konflikt społeczny, polityka wiejska, populizm. 